\title{
OBITUARIO
}

\section{DR. JOHN JAIRO HERNÁNDEZ CASTRO}

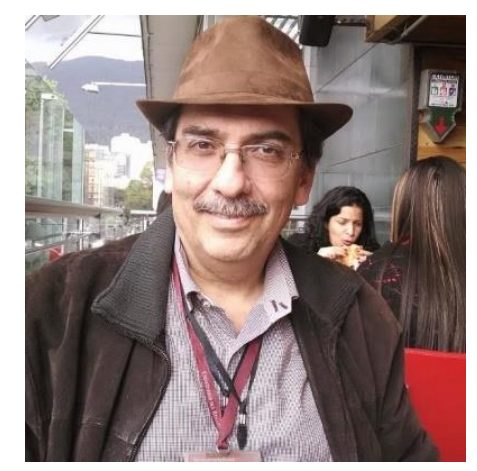

Fecha nacimiento: * 6 de julio de 1957

Fecha fallecimiento: +6 de febrero de 2021

Conocí a John Jairo Hernández Castro cuando cursaba octavo semestre de medicina en el Colegio Mayor del Rosario y nuestra amistad se fue acrecentando a través de los años al ingresar a residencia en neurocirugía en el servicio del Hospital de San José.

Nació en Medellín el 6 de julio de 1957 en el hogar formado por el abogado Eleazar Hernández y Blanca Castro, y acrecentó con los nacimientos de Hernán Darío, odontólogo y Claudia María fisioterapeuta.

Inició sus estudios en el colegio San Bartolomé la Merced en Bogotá graduándose de bachiller en 1975. Hizo sus estudios de medicina en la Universidad del Rosario graduándose en 1984. 
Inició su residencia en neurocirugía inmediatamente después de su grado y durante los cinco años en el servicio fue un estudioso de tiempo completo, mostrando inclinación hacia los procedimientos quirúrgicos de columna vertebral. Corría el año 1985 y por su iniciativa motiva a los miembros del servicio para formar el grupo de dolor, consolidándose en reuniones académicas mensuales con asistencia de médicos de otros servicios congregando múltiples disciplinas.

En 1989 se va a Marsella al Hospital Timone con el fin de especializarse en microcirugía de columna. Al regresar al país y viendo la necesidad de dotar a San José de mejor tecnología diagnostica, en unión de varios médicos y algunos particulares propone la compra de un resonador logrando que el hospital cediera un espacio en el jardín aledaño a la biblioteca para construir en ese lugar un pequeño edificio donde se podría ubicar el equipo, poniéndolo a funcionar el 4 de agosto de 1995, localización que aún se conserva.

Después de algunos años de ejercicio quirúrgico, retoma lo relacionado a dolor convirtiéndose en paliativista y algeciologo dedicándose de lleno a trabajar en manejo del dolor y formar un numeroso grupo de especialistas en la unidad de neurociencias de la facultad de medicina del Colegio Mayor del Rosario y del Hospital Méredi.

Con su grupo de trabajo en dolor tuvo la costumbre de enviar en las mañanas bajo el título del Dolor al Día, artículos y comentarios sobre dolor y cuidados paliativos. Publicó seis libros como autor o coautor y más de cien artículos en revistas indexadas nacionales e internacionales. En líneas de investigación, entre otras escribió sobre anatomía de pares craneanos con resonancia magnética cerebral, 
silla turca vacía, neuroimágenes en psiquiatría, neuralgia del trigémino y consecuencias neuromagnéticas de las adicciones. Distinciones tuvo varias como profesor distinguido del Colegio Mayor del Rosario, reconocimiento de la Asociación Colombiana del Dolor a toda una vida por haber colocado el primer neuroestimulador neuroanalgésico en 2017, distinguido con la Orden de Calatrava del Rosario al mérito laboral y premio de docencia de excelencia en 2010. El Hospital de San José le hizo un reconocimiento por el apoyo al grupo de dolor al celebrar 25 años de funcionamiento. Fue presidente de la Asociación Colombiana para el estudio del dolor (ACED) y miembro activo de la Asociación Internacional del Estudio del Dolor.

Dos aficiones para resaltar, la gran colección de cachuchas adquiridas en los lugares que visitó y participó en congresos y reuniones científicas y sus sombreros de todos los colores y estilos que usó a diario durante varios años. Laboró activamente hasta comienzos de 2016 cuando tuvo una complicación por falla multisistémica después de una cirugía, logrando alguna recuperación y reintegrándose a sus labores hasta agosto del mismo año, pero en diciembre del 2017 una nueva complicación surgió que lo incapacito totalmente para cualquier actividad, falleciendo el 6 de febrero del 2021.

Quiero expresar un sentimiento de gratitud especial para su esposa, Adriana Calderón, quien fue un gran soporte en los últimos años de su enfermedad.

John Jairo, a tal señor todo el honor.

Manuel Roberto Palacios P. Neurocirujano Secretario General Fundación Universitaria de Ciencias de la Salud.

(C) 2021 Fundación Universitaria de Ciencias de la Salud - FUCS. Este es un artículo Open Access bajo la licencia CC BY-NC-ND (http://creativecommons.org/licenses/by-nc-nd/4.0/).

ISSN: 0121-7372 • ISSN electrónico: 2462-991X - REPERT MED CIR. 2021;30(2):195-196

Doi: https://doi.org/10.31260/RepertMedCir.01217372.1232 